\title{
GENDER TRAVEL BEHAVIOUR AND WOMEN MOBILITY CONSTRAINTS IN ILESA, NIGERIA
}

\author{
Musilimu Adeyinka Adetunji ${ }^{1}$ \\ ${ }^{1}$ Department of Geography, Faculty of Arts and Social Sciences, Federal University Lokoja, Kogi State, \\ Nigeria
}

Received 26 June 2012; accepted 20 December 2012

\begin{abstract}
This paper assessed the gender travel behavior in Ilesa, Nigeria. A total of 1,450 copies of a questionnaire were administered to the sampled population in Ilesa, out which 620 men and 580 women completed the questionnaire. Descriptive and inferential statistics were employed for data presentation. The findings revealed that the mean distance traveled to work for men and woman differs in the city. Further analysis revealed that more than $70 \%$ of the women depend on public transport for their day-to-day transactions. Also, $65 \%$ of the men depend on their own personal means of transport to commute to different activity centres in the study area. This implies that men tend to monopolize the personal means of transport available for the entire family. There is a significant relationship between gender travel behavior and trips frequency in the city. The study therefore concluded that there is need to consider gender variation in travel demands particularly with respect to the design and implementation of urban transport policy so as to improve the accessibility characteristics of women to transport services in Ilesa, Nigeria and in other developing countries of the world as a whole.
\end{abstract}

Keywords: women, mobility constraints, infrastructure, transport, policy.

\section{Introduction}

Mobility of persons, goods and services is an important component of any space economy. In addition to being an expression of an individual's free will, mobility takes place with a view to reaching and satisfying such individual's socio-economic, cultural and political needs in different places (Adetunji, 2010). For instance, trips to work, schools, postal services, recreational centers, health centers, relatives, shops/markets and banks are undertaken in order to procure services, which are available in specific locations. The frequency, pattern and complexity of such trips are usually influenced and constrained by physical, demographic, cultural and socioeconomic factors (Asiyanbola, 1999; Boarnet and Crane, 2001; Conger, 2001; Handy and Clifton, 2001; Ironmonger and Norman, 2007; Ipingbemi, 2010).

A review of literature on some of these studies shows that not many of them consider gender travel behaviour of urban residents in the developing cities most especially in medium sized cities in Nigeria. In most cases, women travel patterns are lumped together with other members of the household without cognizance of the fact that apart from domestic work, women are assigned with specific responsibilities that require daily

${ }^{1}$ Corresponding author: musilimu.adetunji@fulokoja.edu.ng 
commuting to various locations different from where they reside. However, the issue of travel need of women is highly imperative in African communities particularly in Nigeria where the population of females is slightly lower than males (NPC, 2006).

Many researches on gender travel characteristics revealed that a dichotomy exists between men and women mobility patterns in both developed and developing countries particularly with respect to modal choice, distance travel and frequency of trips to different locations (Peter, 2000; Oyesiku, 2002). However, the transportation policy in Nigeria does not consider gender travel demands of people which invariably put women at a disadvantage. A study of the gender travel behaviour in towns and cities in developing countries will enable the planners, policy formulators and city managers to fashion out appropriate and sustainable solutions to urban transport problems of women and the possible direction of future development in Nigeria's rapidly growing medium sized towns and cities, hence the need for this research.

\section{Literature Review}

In African communities most especially in Nigeria, there is a difference between the responsibilities a man is expected to perform to his immediate family or community and that which a woman is expected to perform. Generally, a man is expected to cater for the needs of the family. He leaves home in the morning and comes back late in the evening whereas a woman is directly responsible for the domestic activities. She makes trips to market to buy food items, take children to school and health centre whenever the need arises. All these services are located in different places and day to day commuting is required so as to meet the daily need of the family in the society (Peter, 2000). In spite of the fact that women need to visit many important places in order to fulfill their civic rights in the society, they are less accessible to the transport facilities in the family because of the attitude of African men who tend to control the resources of the family and monopolize the transport services available for the need of the household. Even in most cases, vehicles imported to the developing countries are not specifically designed for the needs of women. This circumstance has forced the majority of women in urban centers in African countries to depend on public transport systems which are generally not accessible due to cost and other logistic difficulties.

A technical report on the travel pattern of persons living in Knoxville, U.S.A in 2001, revealed that most trips took between 15 and 30 minutes. On the average, a trip lasted just over 18 minutes. It was also observed that women made more trips than men at a ratio of 3.61 to 3.29 trips per day. Elderly people had the lowest trip rate. For instance, it was observed that those above 65 years made an average of 2.54 trips per day (Conger, 2001). The highest daily trip rate of 4.14 was made by people between ages 35 and 44 years. This group of adults probably takes children to and from school and makes trips to other activities.

In a study of travel behaviour and constraints of low income households and females in Pune, India, Astrop et al. (1996), reported that there are gender variations in household trip frequencies, distance travel and modal choice. According to them, women depend mostly on foot for short trips and rely on public transport particularly bus when long distances are involved, while men depend on motorcycle and scooter to supplement family-owned vehicles to meet their travel demands. In a similar study on the changing 
travel pattern of women in the Netherland, Kalter et al. (2009) affirmed that women spent more time on travelling for household and care-providing activities than men. This ranges from 1.8 to 3.0 hours per week for men and women respectively. The report also shows that women rely mostly on car passenger with a decrease in cycling, public transport and walking contrary to what exists in other developing countries of the world. It is pertinent to note that in African countries, women were mostly responsible for domestic activities, taking children to and from schools, health care services and markets. They also participate in formal activities to earn their livelihood. In another report in Abeokuta metropolis, Oyesiku (2002) reported that the gender modal choice affects pattern of women dressing. According to him, women preferred to use smart dresses when travelling by motorcycle, they abandon the use of traditional dresses in the African setting. It is against this background that this study focuses on gender travel difference in a medium size city of Ilesa in Southwestern Nigeria so as to offer appropriate transportation policy for urban residents in Ilesa and similar other urban centers in Nigeria.

\section{The Study Area}

Ilesa is located on Latitude $7^{\circ} 48^{\prime}$ and $7^{\circ} 6^{\prime}$ North of the Equator and Longitude $4^{\circ} 5^{\prime}$ and $4^{\circ} 7^{\prime}$ East of the Greenwich meridian. The city is about $32 \mathrm{~km}$ North of Ile-Ife (The ancient Yoruba town) with which it shares the same senatorial seat in the upper national legislative chamber, and it is about $30 \mathrm{~km}$ Southwest of Osogbo, Osun State capital.

Farming and trading in varieties of goods are the two major occupations of Ijesa people who are the major inhabitants of Ilesa. As a result of their active involvement in trade across Nigeria, Ijesas are nationally and internationally known as "Osomalo". They are found in all major cities in Nigeria and other West African countries up till early 70s (Peel, 1983). Cash crops like cocoa, palm produce, kolanuts are cultivated for export and long internal distant markets, food crops like yam, rice, maize, cassava, tomato and vegetable are cultivated either for consumption at the family level or for urban daily or periodic markets. Small livestock farming in sheep, goats, chicken, eggs and pigs are carried out by some women either around their premises or at the outskirts of Ilesa where land is available for such purposes (Ogundahunsi, 1995).

There are two major types of public transport systems in Ilesa, these are cars/taxis and motorcycles. The cars/taxis ply the major tarred roads while the motorcycles are seen on both major and local roads. Another public transport system that can be identified in Ilesa is the bus service transport system, but it is no common in the town. The only identified route for this mode is the Roundabout - Campus (Osun State College of Education Ilesa). On Mondays too, market women are conveyed to Sabo market from neighboring towns and villages by bus. The absence of a general bus service system is made evident in the nonavailability of designated bus stops in Ilesa. Although the use of vehicular transport in Ilesa has increased over the years, the commonest mode of urban transport is by foot especially when trips are short and do not involve carrying heavy loads.

There are three large markets in Ilesa. These are Atakunmosa market (Oba's market) Irojo and Imo periodic markets. Commercial activities take place at Atakunmosa market fortnightly while transactions at the other two are done weekly by market women who come from different locations. There are also three other smaller daily markets located in different parts 
of the town. They include Adeti, Okesa and Isokun markets. The smaller markets were established hundreds of years ago and today they are the oldest commercial centers in Ilesa. Different articles of trade such as jewelry, textile and building materials are sold in the bigger markets. In addition to these markets, there are shops along the major streets of the town. For instance, Okesa road, the central road network, Adeti and Isokun streets have numerous medicine stores, hair dressing and beauty salons. Also, a wide variety of health services are provided by both public and private concerns in Ilesa for its teeming population. These range from specialist hospitals to simple health providers. One of such is the Wesley Guild hospital which is an arm of the Obafemi Awolowo University Teaching Hospital at Ile-Ife established by the Methodist Church of Nigeria in 1912. This hospital provides special medical services in the area of psychiatry, gynaecology and medicine. There are many private and other publicly owned clinics, maternities and dispensaries providing general services in the town (Fig. 1).

It is the spatial distribution of these socioeconomic facilities described in the foregoing paragraphs that has given the study area its characteristic land-use patterns which in turn have influenced in no small measure the mobility patterns of residents in Ilesa. There is need to have a comprehensive and proper understanding of gender travel pattern of these various urban trips with a view to formulating appropriate transport policies

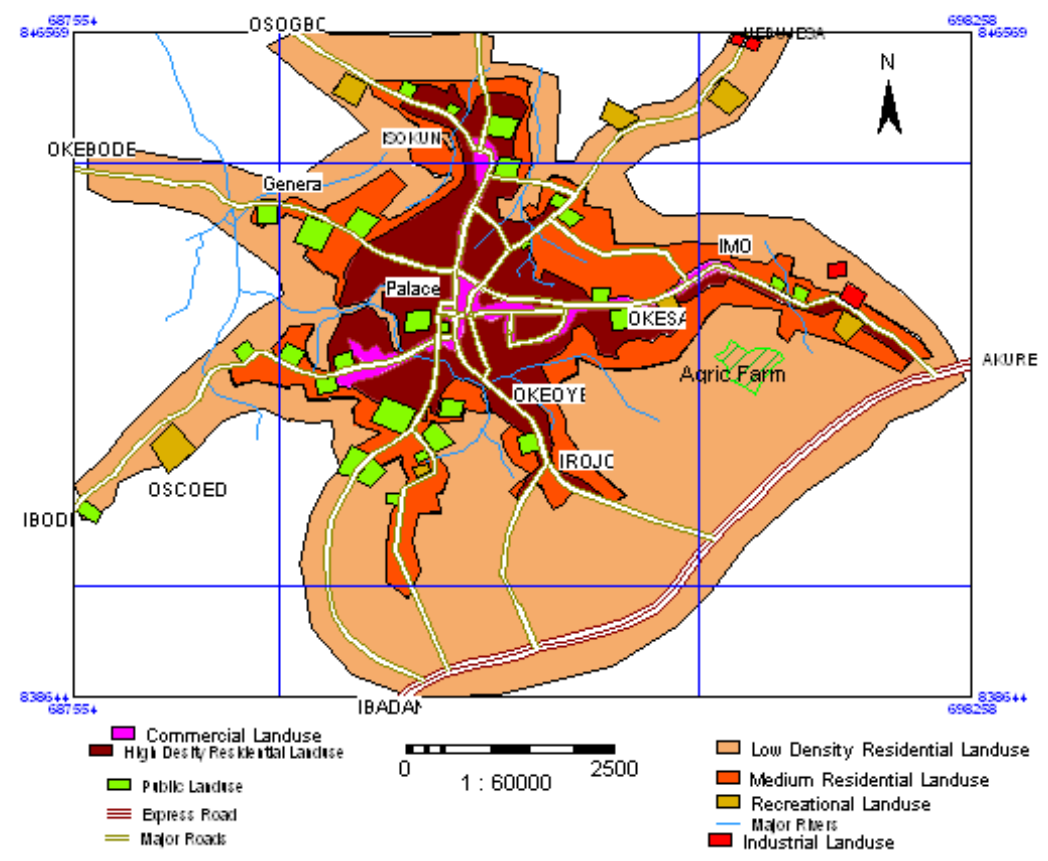

Fig. 1.

Map of Ilesa Showing Major Land Uses that Generates Trips

Source: Author Computation (2010) 
to guarantee gender equal access to transport services and meeting travel demands in Ilesa metropolis and other similar cities in Nigeria in the $21^{\text {st }}$ century.

\section{Methodology}

Primary and secondary sources of data were used for this research. The primary data made use of structured questionnaire to elicit information on trip length, trip frequency and modal choice as well as women mobility constraints in the city. The secondary data were obtained from both Ilesa East and Ilesa West Local Governments, National Population Census Statistics and many other documentary sources in Osun State records.

The study area comprises 21 political wards. These political wards were regrouped into three geographical areas based on land use characteristics and population density, namely: high, medium and low density. In each of the three geographical areas identified, a systematic random sampling procedure was used to select one in every twenty building. In each of the buildings sampled, the questionnaire was administered to the head of household and his wife. A total of 1,450 copies of the questionnaire were administered to the sampled population from which 620 men and 580 women completed the questionnaire. Tables of percentages, graphs and correlation analysis were employed for data presentation. Pearson Product Moment Correlation Analysis was used to analyze the gender travel pattern in the city.

\section{Results of the Findings}

Women generally made more short trips than men in the study area. For instance, Table 1 revealed that the mean distance traveled to work is $5.5 \mathrm{~km}$ for the household in the city. For men, it is $2.86 \mathrm{~km}$ while for woman, it is
$2.65 \mathrm{~km}$. In Africa communities, most especially in developing cities women prefer to work very close to their houses in an attempt to attend to other domestic activities. Even their children returning from schools could easily be taken care of. Further analysis revealed that the average commuting distance to schools for men and woman differs. For men, it is $1.35 \mathrm{~km}$ while for woman, it is $1.08 \mathrm{~km}$. This shows that women made more short trips than men in the study area. The total trip length made by men was $6.38 \mathrm{~km}$ whereas woman made $4.78 \mathrm{~km}$.

\subsection{Gender Occupation and Travel Length}

The nature of the occupation as well as the residential locations of the respondents to different urban activities determines the commuting distance in the city. Table 2 shows that more than $45 \%$ of women who are mostly professionals in the informal sector (traders, farmers and artisans) commute less than $2 \mathrm{~km}$ to work in the city. The majority of this category of the people has their shops or work places very close to their residential units. A significant proportion of women (23\%) who are civil servants commute more than $3 \mathrm{~km}$ to work in the study area. This category of the people claimed that they have comfortable economic status to have home helps to assist them in some domestic activities while they were away from home. More than $50 \%$ men travelled for more than $3 \mathrm{~km}$ to work in the study area.

\subsection{Gender Trip Frequency in llesa (in \%)}

With respect to the trip frequency among the members of the family in Ilesa and many other cities in developing countries, women generally make more trips than men. A critical examination of Table 3 reveals that the average trip made per week by women is 7.52 while that of men is 5.78. In all, the aggregate trip 
Table 1

Gender Mean Trip Length in Ilesa

\begin{tabular}{|c|c|c|c|c|}
\hline $\begin{array}{c}\text { Sex of } \\
\text { Respondents }\end{array}$ & $\begin{array}{c}\text { Distance from } \\
\text { Residence to Work } \\
\text { Place }(\mathbf{k m})\end{array}$ & $\begin{array}{c}\text { Distance from } \\
\text { Residence to School } \\
(\mathbf{k m})\end{array}$ & $\begin{array}{c}\text { Distance from } \\
\text { Residence to Hospital } \\
(\mathbf{k m})\end{array}$ & $\begin{array}{c}\text { Total Travel } \\
\text { Trip (km) }\end{array}$ \\
\hline Men & 2.86 & 1.35 & 2.17 & 6.38 \\
\hline Women & 2.65 & 1.08 & 1.05 & 4.78 \\
\hline Total & 5.51 & 2.43 & 3.22 & 11.16 \\
\hline
\end{tabular}

\section{Table 2}

Gender Occupation in Ilesa (in \%)

\begin{tabular}{|c|c|c|c|c|c|}
\hline Occupation & Gender & Less than $\mathbf{2 ~ k m}$ & $\mathbf{2 - 4} \mathbf{~ k m}$ & Greater than $\mathbf{4 ~ k m}$ & Total \\
\hline \multirow{3}{*}{ Farming } & Male & 21.3 & 21.3 & 57.4 & 100 \\
\cline { 2 - 6 } & Female & 52.6 & 36.8 & 10.6 & 100 \\
\hline \multirow{3}{*}{ Trading } & Male & 53.1 & 41.8 & 5.1 & 100 \\
\cline { 2 - 6 } & Female & 44.6 & 48.8 & 6.6 & 100 \\
\hline \multirow{2}{*}{ Civil Service } & Male & 36.5 & 35.2 & 28.3 & 100 \\
\cline { 2 - 6 } & Female & 50 & 42 & 8 & 100 \\
\hline \multirow{2}{*}{ Artisan } & Male & 56.3 & 36.9 & 6.8 & 100 \\
\cline { 2 - 6 } & Female & 30 & 50 & 20 & 100 \\
\hline
\end{tabular}

made per household per week is 13.33 trips. As shown in Table 3, apart from normal routing work trip, women made an average of 2.16 and 2.64 trips per week for health and shopping trips respectively while men made an average of 1.31 and 0.81 . This can be attributed to the fact that women are mostly responsible for the purchase of food items required by other members of the family and also engage in other activities such as taking children to health care centers when the situation arises.

\subsection{Gender Modal Choice}

It is interesting to note that despite the fact that women made more trips in the city, many of the women interviewed claimed that they are less accessible to transport service. Table 4 reveals that more than $70 \%$ of women depend on public transport (taxi, buses and motorcycles) for their day-to-day transactions. The findings revealed that an approximately $71.15 \%$ of the men own their personal means of transport to commute to work and many other activity centers in the study area while $28.9 \%$ of the women claimed that they occasionally have access to their family means of transport to meet their travel demands. This implies that men tend to monopolize the personal means of transport available for the entire family, whereas in some of the advanced countries of the world, the number of women who have access to personal means of transportation has increased tremendously over the past two decades. For instance, Kalter et al. (2009) reported that women prefer travelling by car 
Table 3

Gender Mean Trip Frequency and their Percentage in the Study Area

\begin{tabular}{|c|c|c|c|c|c|}
\hline $\begin{array}{c}\text { Sex of the } \\
\text { Respondents }\end{array}$ & $\begin{array}{c}\text { Trip } \\
\text { Frequency to } \\
\text { Work }\end{array}$ & $\begin{array}{c}\text { Trip } \\
\text { Frequency to } \\
\text { Hospital }\end{array}$ & $\begin{array}{c}\text { Trip } \\
\text { Frequency to } \\
\text { Shopping }\end{array}$ & $\begin{array}{c}\text { Trip } \\
\text { Frequency to } \\
\text { Social Trips }\end{array}$ & $\begin{array}{c}\text { Total of Trips } \\
\text { for Household }\end{array}$ \\
\hline Male & $2.14(37.4 \%)$ & $1.31(22.7 \%)$ & $0.81(14 \%)$ & $1.52(26.3 \%)$ & $5.78(100 \%)$ \\
\hline Female & $1.73(23 \%)$ & $2.16(28.7 \%)$ & $2.64(35.1 \%)$ & $1.02(13.6 \%)$ & $7.52(100 \%)$ \\
\hline $\begin{array}{c}\text { Total of Trips } \\
\text { for Household }\end{array}$ & $3.87(29 \%)$ & $3.47(26 \%)$ & $3.45(25.9 \%)$ & $2.54(19.1 \%)$ & $13.33(100 \%)$ \\
\hline
\end{tabular}

Table 4

Gender Modal Choice to Activity Centers (in \%)

\begin{tabular}{|c|c|c|c|c|c|c|}
\hline Occupation & Gender & Foot & Motorcycle & Taxi & Bus & Personal car \\
\hline \multirow{3}{*}{ Work } & Male & 48.0 & 65.0 & 35.9 & 54.2 & 71.1 \\
\cline { 2 - 7 } & Female & 52.0 & 35.0 & 64.1 & 45.8 & 28.9 \\
\hline \multirow{3}{*}{ School } & Male & 75.9 & 26.3 & 58.1 & 95.9 & 20.1 \\
\cline { 2 - 7 } & Female & 24.1 & 73.7 & 41.9 & 4.1 & 79.9 \\
\hline \multirow{2}{*}{ Hospital } & Male & 45.7 & 62.0 & 43.0 & 18.4 & 24.2 \\
\cline { 2 - 7 } & Female & 54.3 & 38.0 & 57.0 & 81.6 & 75.8 \\
\hline
\end{tabular}

at a ratio of $30 \mathrm{~km}$ in 1985 to $50 \mathrm{~km}$ in 2007. This is an increase of $60 \%$ of women access to personal car to meet their travel needs.

\subsection{Gender Travel Time to Urban Activity Center}

The amount of time spent by women to work and other urban facilities in the study area is high. Women spent more time to commute to work than men because they rely on foot and sometimes on public transport which are not often readily available. Table 5 reveals that approximately $30.26 \%$ of the women interviewed claimed that they spent more than 30 minutes in transit to work compared to less than $20 \%$ of men who travel for the same purpose, this is as a result of the fact that most men have access to personal means of transport. Further analysis shows that $80.2 \%$ of men spend less than 30 minutes to work, as the majority of men claimed that they have personal means of transport to work in the city. Similar patterns are observable for educational trips in the study area. For instance, $18.18 \%$ of women travel for more than 30 minutes to schools to pick up their children on school days.

Table 6 reveals that the relationship between gender travel behaviour and trips frequency shows a low positive correlation for medical trip $(r=0.25, p<0.01)$ and shopping trips $(r=0.35, p=0.01)$ respectively as these trips are not made unless there are specific necessities to warrant them. However, there is 
Table 5

Gender Travel Time to Urban Activities (in \%)

\begin{tabular}{|c|c|c|c|c|c|}
\hline Urban Activities & Gender & $<30$ minutes & 31-60 minutes & $>60$ minutes & Total \\
\hline \multirow{2}{*}{ Work } & Male & 80.23 & 10.66 & 9.11 & \multirow{2}{*}{100} \\
\hline & Female & 69.74 & 23.54 & 6.73 & \\
\hline \multirow{2}{*}{ School } & Male & 89.61 & 6.49 & 3.90 & \multirow{2}{*}{100} \\
\hline & Female & 81.82 & 15.15 & 3.03 & \\
\hline \multirow{2}{*}{ Hospital } & Male & 92.88 & 5.34 & 1.78 & \multirow{2}{*}{100} \\
\hline & Female & 90.00 & 10.00 & 0.00 & \\
\hline
\end{tabular}

Table 6

Correlation Analysis of Gender Travel Behaviour in Ilesa

\begin{tabular}{|c|c|c|c|c|c|}
\hline & & $\begin{array}{c}\text { Sex of Head } \\
\text { of Household }\end{array}$ & $\begin{array}{c}\text { Trip } \\
\text { Frequency } \\
\text { to Hospital }\end{array}$ & $\begin{array}{c}\text { Frequency } \\
\text { of Trip to } \\
\text { Market }\end{array}$ & $\begin{array}{c}\text { Trip } \\
\text { Frequency } \\
\text { to Work }\end{array}$ \\
\hline \multirow{3}{*}{$\begin{array}{l}\text { Sex of Head of } \\
\text { Household }\end{array}$} & Pearson Correlation & 1 & $0.251\left(^{* *}\right)$ & $0.349\left(^{* *}\right)$ & $-0.148(* *)$ \\
\hline & Sig. (2-tailed) & & 0.000 & 0.000 & 0.000 \\
\hline & $\mathrm{N}$ & 1200 & 1200 & 602 & 1200 \\
\hline \multirow{3}{*}{$\begin{array}{l}\text { Trip Frequency to } \\
\text { Hospital }\end{array}$} & Pearson Correlation & $0.251\left({ }^{* *}\right)$ & 1 & 0.009 & -0.040 \\
\hline & Sig. (2-tailed) & 0.000 & & 0.828 & 0.171 \\
\hline & $\mathrm{N}$ & 1200 & 1200 & 602 & 1200 \\
\hline \multirow{3}{*}{$\begin{array}{c}\text { Frequency of Trip to } \\
\text { Market }\end{array}$} & Pearson Correlation & $0.349(* *)$ & 0.009 & 1 & 0.057 \\
\hline & Sig. (2-tailed) & 0.000 & 0.828 & & 0.162 \\
\hline & $\mathrm{N}$ & 602 & 602 & 602 & 602 \\
\hline \multirow{3}{*}{$\begin{array}{c}\text { Trip Frequency to } \\
\text { Work }\end{array}$} & Pearson Correlation & $-0.148\left(^{* *}\right)$ & -0.040 & 0.057 & 1 \\
\hline & Sig. (2-tailed) & 0.000 & 0.171 & 0.162 & \\
\hline & $\mathrm{N}$ & 1200 & 1200 & 602 & 1200 \\
\hline
\end{tabular}

** Correlation is significant at the 0.01 level (2-tailed).

a negative correlation for work trip frequency at $(r=-0.15, p<0.15)$. This implies that the rate of trip frequency to work has little effect on gender characteristics in the city because every individual has to work in order to earn their livelihood. Also, punctuality to work is the key to the survival of any establishment and efficiency of workers most especially in the civil service. Hence, the ease to commute to work as well the number of hours devoted to work on daily basis is a function of efficient access to transport services in the community or any society.

\section{Conclusion and Recommendation}

This study examined gender travel characteristics in the medium sized city of Ilesa in Osun State of Nigeria. Primary and secondary sources of data were used for this research. The primary data involved the use of a structured questionnaire to elicit information on gender modal choice, travel distance and trip frequency in the city. The findings reveal that women travel characteristics differ from that of men. Women make more short trips than men in the city and are less accessible to personal 
means of transport to commute to different activities centers in the city. The resultant effect of these is that women spend more time on transit which invariable reduces the number of hours devoted to productive activities in Ilesa and many other similar cities in Nigeria. The study therefore recommends that there is need to consider gender variation in travel demands particularly with respect to designing and implementing urban transport policies so as to improve the accessibility characteristics of women to transport services in urban centers in the developing countries of the world.

\section{References}

Adetunji, M.A. 2010. Spatial analysis of urban mobility pattern in Ilesa, Osun State. A PhD Thesis submitted to the Department of Geography, Obafemi Awolowo University, Ile-Ife. 273 p.

Asiyanbola, R.A. 1999. Women intra-urban travel pattern: A case study of Abeokuta, Ogun State, Nigeria Ife, Social Science Review, 17(2): 62-72.

Astrop, A.P.; Christan, M.D.; Babu, D.M. 1996. Urban travel behaviour and constraints of low income households and female in Pune, India. Paper presented at the National Conference on Women's Travel Issues, Baltimore, Maryland. 213-246.

Boarnet, M.; Crane, R. 2001. The influence of land use on travel behavior: specification and estimation strategies, Transportation Research Part A: Policy and Practice. DOI: http://dx.doi.org/10.1016/S0965-8564(00)00019-7, 35(9): 823-845.

Conger, M. 2001. Travel patterns along Knoxville area highways and byways. Technical report series. Available from Internet: <http://archive.Knoxmpc.org/locldata/ onthego.pdf $>$.
Handy, S.L.; Clifton, K.J. 2001. Local shopping as strategy for reducing automobile travel, Transactions, 28(4): 317-346.

Ipingbemi, O. 2010. Travel characteristics and mobility constraints of elderly in Ibadan, Nigeria, Journal of Transport Geography. DOI: http://dx.doi.org/10.1016/j. jtrangeo.2009.05.011, 18(2): 285-291.

Ironmonger, D.; Norman, P. 2007. Travel Behavior of women, men and children: What charges and what says the same? $29^{\text {th }}$ Annual Conference on Time use Research, Washington, DC, USA.

NPC. 2006. National Population Census of the Federal Republic of Nigeria, Abuja National Population Commission.

Ogundahunsi, D.S. 1995. An assessment of development control in Ilesa Local Government, Osun State. An Unpublished M.Sc. Thesis, Department of Urban and Regional Planning, Obafemi Awolowo University, IleIfe. $131 \mathrm{p}$.

Kalter, M.J.O.; Harms, L.; Jorritsma, P. 2009. Changing travel patterns of women in the Netherlands. 31st Conference of the International Association for Time Use Research, Leuphana University Lüneburg, Germany. 23-25.

Oyesiku, O.O. 2002. From womb to tomb. 24th Inaugural lecture, Olabisi Onabanjo University.

Peel, J.D.Y. 1983. Ijesa and Nigerians. The incorporation of a Yoruba kingdom 1890s-1970s. Cambridge University Press, Cambridge, London. 333 p.

Peter, D. 2000. Gender and transport in developing countries: A background paper in preparation for CSD9. London/Berlin: UNED forum/German Federal Environment Ministry. Available from Internet: <http:// www.earthsummit2002.org/workshop/bpaper.htm >. 


\section{KARAKTERISTIKE PUTOVANJA U ODNOSU NA POL I OGRANIČENJA MOBILNOSTI ŽENA U ILESI, NIGERIJA}

\section{Musilimu Adeyinka Adetunji}

Sažetak: U radu su analizirane karakteristike putovanja u odnosu na pol u Ilesi, Nigerija. Anketom je obuhvaćena populacija od ukupno 1450 ispitanika, od toga, 620 muškaraca i 580 žena. Za analizu podataka korišćene su deskriptivna i deduktivna statistička analiza. Istraživanja su pokazala da se srednja dužina putovanja do radnog mesta u gradu razlikuje za muškarce i žene. Detaljna analiza je pokazala da više od $70 \%$ žena koristi javni transport za realizaciju svojih svakodnevnih putovanja. Takođe, 65\% muškaraca koristi sopstveni, privatni vid prevoza za putovanja do različitih mesta atrakcije na posmatranom području. Rezultati ukazuju na činjenicu da muškarci teže da zadrže privatni vid prevoza, koji je na raspolaganju celoj porodici, za sopstvene potrebe. Uočena je i značajna veza između karakteristika putovanja osoba prema polu i učestanosti putovanja u gradu. U zaključku studije je utvrđeno da postoji potreba za razmatranjem varijacije transportnih zahteva u odnosu na pol, posebno u smislu definisanja i primene politike javnog gradskog prevoza kojom bi se povećala pristupačnost transportnih usluga ženskoj populaciji u Ilesi (Nigerija), kao i u drugim zemljama u razvoju.

Ključne reči: žene, ograničenja mobilnosti, infrastruktura, transport, politika. 